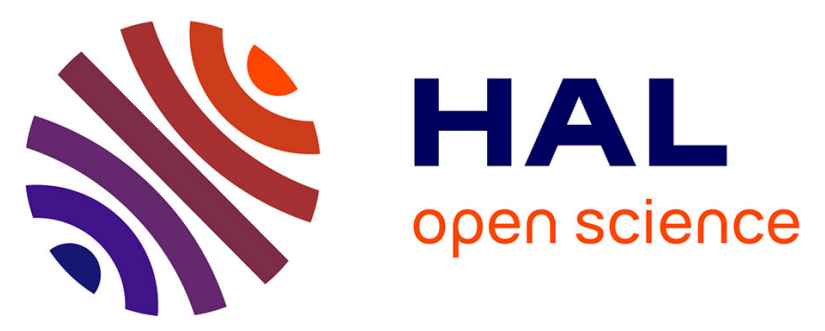

\title{
Hellfest: The Thing That Should Not Be. Local Perceptions and Catholic Discourses on Metal Culture in France
}

Gérôme Guibert, Jedediah Sklower

\section{- To cite this version:}

Gérôme Guibert, Jedediah Sklower. Hellfest: The Thing That Should Not Be. Local Perceptions and Catholic Discourses on Metal Culture in France. Popular Music History, 2012, 6 (2), pp.100-115. 10.1558/pomh.v6i1/2.100 . hal-02185904

\section{HAL Id: hal-02185904 \\ https://hal.science/hal-02185904}

Submitted on 23 Jul 2021

HAL is a multi-disciplinary open access archive for the deposit and dissemination of scientific research documents, whether they are published or not. The documents may come from teaching and research institutions in France or abroad, or from public or private research centers.
L'archive ouverte pluridisciplinaire HAL, est destinée au dépôt et à la diffusion de documents scientifiques de niveau recherche, publiés ou non, émanant des établissements d'enseignement et de recherche français ou étrangers, des laboratoires publics ou privés. 
Text published in Popular Music History, 6.2, Sheffield, Equinox Publishing, 2012, p. 100-115 (in the "heavy metal controversies and counterculture" special issue edited by T. Hjelm, K. Kahn-Harris and M. Levine)

\title{
"Hellfest: The Thing That Should Not Be?
}

\section{Local Perceptions and Catholic Discourses on Metal Culture in France" \\ by}

Gérôme Guibert and Jedediah Sklower

\begin{abstract}
"Il ne faut pas prendre les enfants du Bon Dieu pour des canards sauvages.,

"Cercle des Trois Provinces" anonymous letter to G. Guibert (2008)

"Let me ask you a quick question - which by the way failed to come up at the trial which they had: What performer wants his fucking audience dead?"
\end{abstract}

Bill Hicks: Relentless (1992)

Based on the number of performers, audience and budget, Hellfest is the most important metal music festival in France. It has been held every year since 2006, for three days around June $20^{\text {th }}$, in Clisson, a small town of 7.000 inhabitants, in the county of Loire-Atlantique in the West of France. It has not stopped growing since its birth: The first time, 62 groups played on two stages for 20.000 people, with a budget amounting to about 800.000 euros. In 2010, 114 groups played on four stages, 72.000 metalheads came, and the budget 
reached 3.500.000 euros.

The festival takes place in a region where metal music events have been rare. In general, metal in France remains an underground and little-known subculture. Compared to the other festivals in the region of Les Pays de la Loire, the Hellfest's economic functioning is an exception, as it is self-financed (subsidies only account for $2 \%$ of the budget, while the average is $25 \%$ - cf. Guibert 2008, 4) and based on an individual, private initiative. Its growth is thus all the more impressive when one considers that subsidies represent on average a quarter of the budget of regional popular music festivals (Guibert, 2008). This success also relies upon the strong number of foreigners who attend the shows (35\% of the audience, a national record). Finally, the Hellfest's instigator is a "local boy": Benjamin Barbaud, now 29 years-old, who grew up, played soccer and learned his catechism in Clisson. Obviously, his personal history makes it easier to understand how it was possible to organize the festival there. He gathered a team of mainly local residents to put everything in place. A fast learner, he basically learned by doing, having first created a hardcore punk event, the Fury Fest (2002-2005), before deciding to create one dedicated to metal, with Korn as the 2006 edition's top of the bill, and Kiss as that of 2010's. Looking back to the early years, he says:

We had fun programming GBH and the Dead Kennedys, but it didn't work out that well, which is why we turned to metal. Metalheads spend 
more money, while punks will have a hard time paying 100 euros for a seat. It's not their state of mind, it's tough explaining to them that we don't get subsidies like general public festivals. [...] We always wanted to bring bands from the eighties, but in the beginning we just didn't have the money. [...] People made unpleasant comments about Kiss, who aren't extreme, but we just thought that there should be a space for that type of bands in France. We did great with Manowar last year [...] Since I've been organizing the Hellfest, I've rediscovered metal." (Chelley and Manœuvre 2010, 9).

Barbaud is a pragmatist: he responds to an unsatisfied demand, and that is how he justifies his choices of acts, before considering aesthetic or social reasons. This explains why he invites black metal bands - which are, however, a minority in the festival's program.

\section{Birth of Ignorance: The ambivalent 2006-2007 reactions}

The establishment of the Hellfest immediately sparked off important debates. Clisson inhabitants were nervous at the possibility of being disturbed by a rock festival (huge crowd, noise, lack of safety). Yet in 2006, the town hall, which had a right-wing majority, emphasized its economic benefits.

The outcome of the first festival in 2006 was positive. Clisson storekeepers were quite satisfied with the economic impact of the event (lodging, catering, transportation, tourism). Although some of them complained of the nuisances 
(traffic, noise, etc.), there weren't any incidents. The police noted that the law was universally respected. Considering the festival's size, problems of violence or offences were barely visible, and the local population, although sometimes shocked by what they perceived as, in the dress codes and the music itself, aggressiveness, was surprised by the festival-goers’ polite behaviour: “20.000 festival-goers with their strange way of dressing and their 'shrieking' music: the locals expected the worst. But finally, the Hellfest got almost unanimous support. The various Cassandras got nothing for their pains. [...] The attitude, the costume, the music may seem provoking. The attitude isn't. 'They are extremely polite and respectful...' This is what all those who were in contact with them - the mayor and his deputies, municipal counselors, the police, rescue workers, shopkeepers and the population - said." (Ouest France, june $27^{\text {th }}, 2006$, p. 6). Concerns about public safety or "morality" remained lowlevel, largely because the festival's team adopted a proactive attitude, overcoming the problems of organization, improving the reception conditions for festival-goers and being open to requests from Clisson inhabitants. Local economic agents also insisted that the festival keep on going, and by the fall of 2006, the second edition (Hellfest 2007) was authorized by the city council. Collaborations with the local civil society developed during the preparations for the following editions (volunteer work, animations, set-building, cleaningup and a "green-friendly" festival).

At Hellfest 2007, the organizers encountered management problems due to the 
terrible weather and the unrelenting rain - they nicknamed it "Woodstock edition" for that reason. However, these climatic hazards ended up being beneficial, as many "Clissonnais" helped the festival-goers out, welcoming them into their homes or garages. Generally speaking, links between both populations grew stronger ${ }^{\mathrm{iii}}$.

\section{By Demons Be Driven: The 2008 turning point}

While the festival was taking root in Clisson, the year 2008 was also a polemical turning point. Violently hostile reactions surfaced sporadically during the months preceding the event, followed by a growth in arguments against the festival. The growth of the internet, and in particular of lobbyist blogs, accompanied the debates.

Municipal elections took place in early 2008, and in Clisson the outgoing mayor was defeated by his left-wing Catholic opponent. The latter had an ambiguous position vis-à-vis the Hellfest, which enabled him to gather opponents into his camp without alienating his supporters. He insisted upon the festival's economic and tourist importance, and acknowledged the right for any musical expression to have a platform. But at the same time, he denounced the attacks against Christians in the lyrics of some of the groups invited. The opponents' rhetoric gained in precision, following the visit, early 2008, of father Benoît Domergue, a priest with a $\mathrm{PhD}$ in theology, who studied gothic 
and metal culture, and who offered several meetings on the topic in Clisson. One of them was public, and was attended by about 300 people, another was organized behind closed doors for the city council. Domergue also met both of Clisson's priests.

There is something odd about Father Domergue's strategy. During the festival, he appeared as a moderate. He acknowledged the legitimacy of heavy metal as a culture, while condemning its anti-Christian excesses. He wanted a say in the festival's programming, but only in order to separate the wheat from the chaff, and set aside the bands that were too extreme (he mentioned Belphegor, Dimmu Borgir and Impaled Nazarene). Yet, one can only be surprised by the huge gap between what he would say in public and what he wrote in his book on extreme music (Domergue 2000). In the latter, he proposes a description of Satanist metal, listing dozens of bands, translating the most shocking lyrics which, undeniably, are easy to find. However, he makes a naïve interpretation of them, as he does for example with bands such as Slipknot or Slayer, one of the apparently most vehemently anti-Christian bands, whose lead singer, Tom Arraya, nonetheless sincerely adopts the Christian faith. As Deena Weinstein (2000) or Fabien Hein (2006) put it, calls for the eradication of Christianity should not be taken literally. Domergue establishes this list as if there were a systematic homogeneity between the musicians' intent and the forms taken by their music. That is to say that sound forms are always perfectly adapted and coherent with lyrics and vice-versa, that they are the smoothest, the most 
faithful vehicle of the explicit message that they are supposed to promote in unison. This fallacious faith in the flat coherence of the musical sign as a whole makes Domergue incapable of conceiving that musicians and audiences can play with meaning and its degrees of seriousness/literalness, that musicians can associate intentions, texts to musical forms that are radically opposed to the monolithical signification he considers the obvious one. The presence of several "Christian core" (see Moberg in this volume) bands at each edition of the festival - or, for that matter, of a great majority of non-Satanist bands playing the same type of music - could have given him some sort of clue pointing to the possibility of ambivalence or polysemy, if not voluntary "misappropriations".

The second stage of Domergue's reasoning was that formally Satanic music, produced by a Satanist intention, can only have, in an appropriate context (the "collective trance" created in metal concerts as he puts it), Satanic effects. These effects are, first, moral, as the music creates despair, depression, and morbid fascination. Second, they are proselytic: music is a technique of converting people to Satanism, based on the conjunction of the mesmerizing show - he mentions "bewitchment" - and this moral weakness. For example, Domergue writes:

If one considers Black or Death Metal, one can easily see that there is an automatic and mechanical relationship between the tones, the 
rhythms and the sonorities of this type of music and those who listen to it [...] which also results from magic.” (Domergue, 2000, 84).

In order to seal up this harmonious chain of meaning, no matter how powerfully corruptive Satanist metal is, the listener still has to be "helpless to resist" its power (Walser 1993, 141). During his 2008 conference, Domergue said that "most young people I meet are lost lambs, but not wolves. For example, some Gothics [sic] came to see me so that I could hear their confessions. These young people swallow the words of a band like Slayer, and their latest anti-Christian album,"iv Comments such as this that deny any form of agency to the metal listener who presents symptoms of psychological or moral fragility, are legion in the book and his meetings, as well as being present in the discourse of all Catholic opponents to the Hellfest. As Robert Wright puts it, while examining the controversies around Marilyn Manson in the United States: "the very act of listening becomes symptomatic of antisocial behaviour and even suicidal tendencies" (Wright 2000, 373). Listening is the location where this type of discourse finds its most fertile point of entry, where the Satanist threat can contemplate its ravages, within the intimacy of the notquite-innocent and dangerously alienable soul it lives to musically deprave. This alleged corruption of course justifies all types of inquisitions wished for by moral authorities: assertion of norms, detection of symptoms and proposal of therapeutics (including, in this case, exorcism ${ }^{\mathrm{v}}$ ). To sum things up, there is a perfect similarity between intentions, forms and effects, which is only possible 
provided that the meaning is petrified, and that the two first instances (the intentions and the musical form) of the musical sign have a direct power on the third (the listener), which is deprived of any autonomous will or sensibility.

While he highlights a certain form of magic and the corrupting psychological potency within the substance of metal, Domergue's discursive strategy carries out a certain moral technique of power that, by mobilizing a whole set of eclectic rhetorical tactics, aims at producing a representation of the metal world that could hook up with vague anxieties within the French Catholic milieu, if not State authorities. The cultural and demographic context of Catholicism in France is one of decline and reaction to different real or perceived "assaults": loss of flock, influence and authority, multiple recent scandals, failure to impose the idea of a "Christian origin" of Europe in its Constitution, fear of Islam, and beyond that, the French anticlerical tradition [Schlegel 2009, 7-16]. Thus, finding/inventing heinous and dangerous enemies enables the Church to present itself as "victim" and exclusive "scapegoat" of rampant "cathophobia", and can be an efficient way to mobilize troops. Taking inspiration from Foucault (2004, 68-69), we could call this strategy a government of senses (Sklower 2008, 211): discursive techniques aimed at producing, with the cooperation of the receptive subject, representations and sensorial (in this case, listening) practices that take root in the pre-existing fears, in order to unite a community in the rejection of a subculture. Not only a peripheral "excess", but maybe a central revelator of recent evolutions within society. In this case, an 
ambiguous strategy, one that tries to bind a community together in a fantasmatic fear while still trying to debate with the opponents. The goal is to have some legitimacy within both worlds, a position from which negotiating censorship is possible.

Clisson's town hall wasn't insensitive to the more presentable and relatively consensual aspects of Father Domergue's discourse. As representatives of many of the town's believers, the local authorities kept in mind the idea that metal could promote an insidious and dangerous message. They found further confirmation of their suspicions in the conclusions of the Miviludes (the "Interministerial Mission of Vigilance and Fight against Sectarian Excesses", a State organism in charge of informing the authorities and the public about various sectarian dangers - for example, the 2009 annual report dealt with the influence of "New Age" movements) that released its analyses about the "growing influence" of Satanism at the same moment (Spring 2008). It is important to offer a brief description of these analyses, as they represent the authority of the State, and thus - one would hope ${ }^{\mathrm{vi}}$ - a neutral, scientific and balanced point of view on the reality of Satanism in France. These conclusions were constantly referred to by the festival's opponents, radical or not (the "Confédération Nationale des Associations de Familles Catholiques", the association "Catholiques en Campagne", the "Cercle des Trois Provinces" quoted at the beginning of this chapter, as well as many Catholic blogs). 
What is interesting about this report is that one can find a familiar list of the different "symptoms" and "signs" that must "alert" parents on the risks that their children run when they listen to diabolical music, such as:

- A "radical change in the dress code, and in particular the adoption of black as the only reference",

- Forms of "withdrawal" (rejecting usual activities, family, school etc.),

- "a total rejection of traditional religions, combined with a growing fascination for pagan emblems, military clothing and relics",

- "melancholic tendencies",

- "musical tastes orientated towards the more violent forms of metal",

- "the excessive consumption of scary and horror movies, as well as of roleplaying games or video games that surf on the same morbid themes",

- The viewing of "Internet websites, forums and blogs" that deal with "provocation, Satanism, esotericism, pornography (and paedophilia), mind reading and political extremism

- And, among many others, this poetically elliptical one: "the attraction to cultural consumer goods forbidden for any younger than age 16" (Miviludes 2006, 79-80).

A short 2004 preliminary report highlighted "the assiduous frequentation of metal concerts" as "not without risk (nearly-hypnotic atmospheres that encourage states of trance, subliminal messages calling for acting out and stimulating suicidal drives, etc.)" (Miviludes 2004, 2), as well as "incitement to hatred" and "anti-Semitic allusions to paganism and nationalism", not to mention the "sometimes proselyte, fervent Satanists" who haunt the "nebula of fans of Black Metal idols" - many elements that one also finds in Domergue's book as well as on various anti-Hellfest blogs and texts. 
Adopting these signs can thus indicate a form of "subjugation" ("mise sous influence"): anything counter-cultural about these practices, anything that can bear a sense of aesthetic identification, that can create values, a sense of community, is immediately rejected as a deleterious manipulation. The Satanist sign, once again, carries a harmful scheme, the threat of dispossession of the self. As Robert Walser puts it, Tipper Gore-type critics “imagine that fans are passive, unable to resist the pernicious messages of heavy metal, and thus they themselves commit the sort of dehumanization they ascribe to popular culture. They make fans into dupes without agency or subjectivity" (Walser 1993, 144). Of course, the 2006 report clearly says that there is no "direct causality between listening to Satanist music and acting out", but there still are "indirect effects" that can constitute a "favourable terrain for acting out": "the connection during concerts with practicing and proselyte Satanists; acting out of what is promoted in the songs' lyrics" and "deep rupture with common family culture" (Miviludes 2006, 94).

The fact is that the Miviludes never discusses the "sectarian excesses" that can exist in legitimate religions, and that could formally reveal many affinities with the definitions it proposes of this subculture's functioning; nor would it indulge in analyzing, for example, the moral weakness, the confusion that can push some to seek refuge within the more respectable belief systems and religious communities, or the examples of charlatanism that exist within some of them. This discourse is proposed in the name of a certain normative - if not religious 
- order of signs, aimed at the exposure of subcultural forms, as much, if not more, as it is in the name of cultural (freedom of religion, tolerance) and "biopolitical" (our youth's moral health - or rather, the norms that determine the appearance of moral health -, peoples' security) imperatives (Foucault 1976, 184; 2004, 233-237). The insistence on "influence" and "acting out" here, obviously, in a more scientific (psychoanalytical) register than in Domergue's - reveals the anxiety concerning familial and social stability, which cannot go without cultural (moral, aesthetic) prescriptions. Once again, culture is analyzed monosemantically, the listening subject is deprived of any capacity of creating significance through autonomous practices (a subjectivation), that in fact "undo" this illusory power (De Certeau 1990, 239242; Rancière 2008, 18-20/48-49).

Strengthened by this conjuncture, the festival's opponents decided to lead public campaigns against the Hellfest. There was for instance the "Cercle des Trois Provinces" (Circle of the Three Provinces), a Catholic association politically and ideologically rooted in the extreme-right movement ${ }^{\mathrm{vii}}$. They mainly used posters and sent letters to the media and festival's supporters (Ben Barbaud received one, in which he was told that he would have to "answer before God for his deeds"viii...), in which they mixed religious texts, prophecies, prayers, as well as odd articles, for example on Aids in Africa and the solutions recommended by Pope John-Paul II (abstinence etc.). These tracts proposed many elements typical of the rhetoric we analyzed above in a more extreme and caricatured way: condemnation of "anti-Christian racism", of the 
authorities' "criminal" behaviour, in financing an evil festival in the context of a "multiplication of tomb desecrations in cemeteries", Satanist proselytism which "harnesses the weakness of certain young people who go through an identity, mental crisis, lack future perspectives, break with their family, drop out of school" thanks to "magical", "sexual" and "destructive rituals" and their attraction to anything "morbid" or "esoteric" etc.

A right-wing association of Clisson inhabitants wanted the festival to disappear, demanding the "protection of public order and of youth" (Hebdo Sèvres et Maine, May $\left.8^{\text {th }}, 2008,3\right)$. In this case, the evocation of humanist and republican or traditional principles, as well of course as the defence of teenagers, constituted a means by which these groups propounded their values within the broader ethical field of civil society and the authorities.

Quite quickly though, the church of Clisson distanced itself from such positions. The festival's third edition dispelled all doubts, as it took place under a bright sky, and without any major incidents. The exchanges between festivalgoers and local inhabitants had by then become part of the "folklore". The local library presented books on the subject, inviting the authors to present their work, the festival showed films on metal culture in Clisson's movie theatre. More and more people also provided shelter for the metal fans.

III. God Gave Rock 'n' Roll to Everyone - the 2009-2010 confrontation 
The Hellfest came out strengthened by the 2008 edition, even though the most conservative Catholics kept on protesting about the Satanist factory it was supposed to be $\mathrm{e}^{\mathrm{ix}}$. The festival's organizers feared a big assault because of Marilyn Manson's top billing on June $20^{\text {th }}$, but no such thing happened. In the Clisson parish bulletin, the priest called for serenity and opened permanent prayer services during the entire festival (Ouest France, June $10^{\text {th }}, 2009,8$ ).

But a broader attack coming from national right-wing political parties and traditionalist Catholic blogs took shape shortly before the beginning of the festival, in the form of questioning the (scarce) public subsidies granted by the General Council of the Loire Atlantique county and the Regional Council of the Pays de la Loire. A small right-wing party close to the government's UMP party (Union for a Popular Movement), the CNI (National Independents Centre) opened the assault, declaring that "the limits of the unbearable have been crossed [...] Our taxes serve the diffusion of extremely violent messages" (Presse Océan, June $20^{\text {th }}, 2009,2$ ). The local representation of the UNI (the main UMP-affiliated students association) and Catholic associations pursued the same agenda ${ }^{\mathrm{x}}$. These different organizations wanted to put pressure on the Hellfest by email and phone messages sent to the festival's public or private (Kronenbourg, Coca-Cola) sponsors and their servers and telephone switchboards were overwhelmed for several days. Coca-Cola, who supported the festival with its Monster Energy Drink, declared in early July that it would withdraw from the festival (however, it agreed to come back in 2010). Various "interest groups" reacted to these attacks. First, those who 
supported the Hellfest, or more globally, metal. Specialized blogs and websites (Metallorgy, spirit-of-metal, Metal Impact...) relayed the information and criticized it. Fans created a specific website in defence of the festival (proHellfest.fr), which gathered the many initiatives, such as Facebook groups $^{\mathrm{xi}}$. Professionals of the cultural field mobilized by proposing a petition: "Appel à soutien au Hellfest: pour la diversité artistique" (Call for the support of the Hellfest: for artistic diversity) ${ }^{\mathrm{xii}}$. As with the year before, it was only days before the festival that the polemic developed, losing force only days after. It was scarcely touched on by the media, as once again there were no incidents in 2009. Security companies even said it was their favourite event in the West of France because of its peaceful nature (Hebdo Sèvre et Maine, June $\left.25^{\text {th }}, 2009,11\right)$. Besides, the programming of bands such as Europe and Mötley Crüe broadened its appeal within the metal community.

Robert Culat, priest of the Carpentras parish and an active supporter of metal, intervened during the May 2009 debate in Clisson. His perception of the metal milieu opposes that of Father Domergue's in many ways, as well as, $a$ fortiori, that of the more fundamentalist Catholic groups. He loves metal (Opeth being his favourite), listens to many anti-Christian bands (like Emperor), and even wrote a book on his experience and encounter with this world (Culat 2008), in which he interviewed dozens of fans about their relationship to this music. In a June $28^{\text {th }}, 2009$ post on his myspace, "Padre Bob" delivered a digest of his thoughts on metal, in which he criticized the caricatured vision proposed by extremist Catholics. He used many biblical 
references, Church texts, such as the Catholic social teaching, or various encyclics, in order to dispel the accusation of Satanism and reverse it against "true Satanism", i.e. hedonistic individualism in contemporary capitalism.

Culat finds positive, and even Christian values within the metal world, such as solidarity (he mentions the grass-root fundraising that was organized to help Chuck Shuldiner ${ }^{\text {xiii }}$ ). What the anti-Hellfest Catholics consider as perversion or dangerous passivity, for him, becomes the sign of a praiseworthy spiritual craving: one mustn't judge “those who seem to refuse God”, because "certain oppositions can be closer to a true religious attitude than soulless conformism" and "sometimes, 'blasphemous' words uttered by Atheists can be the expression of a more or less conscious spiritual research." Thus, rather than condemning without knowing, one must follow Paul VI's precepts (the "bête noire" of Catholic fundamentalists), that is to "get closer to the profane society" and try to "evangelize the culture, the milieus and the mentalities so that the reference to God find its right place". Thus, the adoption of signs, and even of a specific liturgy by metal fans should not be considered as a threat to Christianity anymore, but as a godsend in disguise for a new evangelization.

To moral fundamentalism, he opposes a rationale of pastoral efficiency: "Is asking for censorship or banning the solution to promote the cause of the Gospel and of faith among the young people that are generally very far from Christianity?" ${ }^{\text {xiv }}$ he asks. His discourse is not one of universal tolerance ${ }^{\mathrm{xv}}$, but one of subcultural sympathy. He believes in the spiritual power of the metal community, in its capacity to recognize the true meaning of its practices. The 
desires that underpin the adherence to metal signs reveal virtues that are absolutely compatible with the Christian faith and way of life, specifically: love, understanding and evangelization vs. hatred, stereotypes and inquisition.

The year 2010 was one of national controversies. Adopted by the locals, the Hellfest had become a much-loved, and 72.000 fans came to hear the Deftones, Fear Factory, Infectious Grooves, Sepultura, Slayer, Carcass, Alice Cooper and Kiss, as well as the 108 other bands. Nonetheless, the polemics resumed, starting earlier than in previous years and reaching an unprecedented scale. Once again, the political context was responsible for making the argument an issue, as regional elections took place in March 2010. On March $11^{\text {th }}$, during a meeting of the right-wing regional opposition, Catholic and xenophobic politician Philippe de Villiers stated that "our values aren't the ones that push the actual Regional Council to finance a Satanist festival!". In the heat of the electoral campaign, Christine Boutin, former minister and president of the Christian Democrat party (equally in the region's political opposition) disclosed on her website a letter sent to brewer Kronenbourg, asking the company if it was "relevant to associate [their] image to a festival that promotes and encourages a culture of death?"xvi . An idiom that carries all the ex-minister's struggles against other faces of this "culture" - abortion, homosexuality... To this literal and monosemic interpretation of the sign "death", one could oppose the testimony of death metal musician Dan Saladin, gathered by Harris Berger: "The energy of a death metal performance, and the 
attendant subcultural community-building that these musicians so enthusiastically participated in, is pursued as a pro-active response to the apathy, a way of overcoming hopelessness" (Berger 1999, 173), or even Marilyn Manson's answer to such accusations (Wright 2000, 375). The apparent morbidity of the metal milieu is in fact often the sign of a struggle against the threat of insensibility or spiritlessness: a conjuration of melancholy, an aspiration for energy, a research of community.

On March $30^{\text {th }}$, socialist deputy Patrick Roy reacted by interrogating Minister of Culture Frédéric Mitterrand, during a parliamentary questions. The latter played down the controversy while emphasising that the State didn't subsidize the festival. The left won the elections, and the controversy disappeared during the month of April. Two elements must be noted here. First, this exposure of the Hellfest proved a lucrative one for the Hellfest's organizers, as the number of tickets sold grew again in 2010. Secondly, the national media globally defended the Hellfest. Even TF1, the most popular French private television channel, although it did show in its reportage on the festival $^{\text {xvii }}$ a "shocking" backstage Satanist ritual whereby the members of Scandinavian band Watain covered their faces with animal blood before their performance, insisted predominantly on the "friendly atmosphere" that reigned during the whole event. 


\section{Conclusion}

From this brief review of the controversies surrounding the Hellfest, one can identify two fundamental tendencies. First, on a local level, the perception of the festival - and through it, of metal - evolved from questions and incomprehension to enthusiasm and support. One could consider these debates a Habermassian public sphere (Habermas 1997) in the sense that practical reason and consensus prevailed. During public debates, the various parties were invited to have their say, and organizers tried to deal with some of the critics. But on the national level, it is a public sphere according to Nancy Fraser's definition (Fraser 1992): antagonistic, impassioned, and animated by subaltern counter-publics. The public dominant in previous eras (Catholics opposed to blasphemy and symbolic attacks) has progressively become a minority, as the influence of the Church has declined in French society. Rock's partisans now promote potent norms.

Any strategy of cultural and moral struggle summons a various set of discourses and rhetorical strategies. Specifically in this case, Catholic opponents to the festival proposed on the one hand a moral and aesthetic one, on the value and power of a given cultural sign, and the means by which authorities should fight against it. On the other hand, they used various cultural strategies of struggle that followed an axis going from total ideological intransigence to a set of flexible tactics of negotiation with opponents or other institutions' values. Among the extremists - in this case, Catholic 
fundamentalists -, there was the antagonistic and closed assertion of a conservative value and belief system, and among the more pragmatic, the search for some sort of "settlement" between the ideological systems supported by the different agents of the polemic. This meant convincing the authorities to put limits on freedom of speech in the name of tolerance (a Republican, secular value), and thus accept the censorship of violently anti-Christian bands (their political goal). These strategies reveal different perceptions of each agent's capacity to defend its values at the moment of the struggle ("should we confront or negotiate?") as well as, eventually, interpretations of the state or "origin" of the loss of influence ("what does the existence of a Satanist festival in this "Catholic" country say about the evolution of our authority?").

The question of the limit imposed on what metal bands can express cannot be judged independently from this context of broader relationships in which the targeted authorities (in this case, the Church, but also eventually others such as the State, the family, the workplace etc.) are entangled. Indeed, the argument according to which similar attacks on Judaism or Islam wouldn't be tolerated is quite right, if considered in abstracto. But the difference in this case is that the Catholic Church, despite its long-term decline in influence symbolically remains a dominant moral figure, historically and geographically rooted (especially in Western France), benefiting from traditional privileges (State-funded private schools, for example) as well as recent reactionary presidential endorsements ${ }^{\mathrm{xviii}}$. This is where the French context is different from that of the United-States, although the comparison with the Tipper 
Gore/PMRC debates shows many strong similarities (Walser 1993, 138-142) notably when it comes to "preserving" youth's moral health. In France, Christianity is a weakening yet symbolically potent figure of moral order and repression. All of this makes it a purely metaphoric - thus caricatured - target of counter-cultural rebellious desires within the vast majority of metal fandom. Just as the stereotypical depictions of the latter by certain Catholic groups serve as a pretext to galvanize opposition against its specific "victimization" as a religion, while using at the same time typically secular "multiculturalist" rhetorics (denouncing intolerance and lack of respect for freedom of religion).

The question of the limits to freedom of expression is however a problematic one for the metal world. When can one identify the objective signification of a song and its concrete dangers (Kahn-Harris 2003)? If we draw these limits, do we not risk reifying signification when we previously set ourselves up as champions of its collective construction? This same confidence in the "hijacking" of signification operated by the listener represents a chance or a threat depending on the circumstances, the intentions, the interactions, the needs of those who preside over the "choices" guiding such practices... A Western band virulently criticizing Islam offers little doubt about its xenophobia, whereas the wearing of T-shirts with the logo of explicit antiSemitic bands by Israeli metal fans - although quite meaningful - obviously does not point to a literal identification (Kahn-Harris 2002, 126).

Indeed, metal maintains a counter-cultural aura as long as it keeps sparking off such polemics - and it is a subculture that feeds on provocation 
and excess. From this point of view, the strategy of the Hellfest's organizers, consisting in successfully portraying metalheads as sweet and harmless boys can be problematic: could these ultra-virile and hyper-mean musical assaults only be a farce, a sort of musical translation of wrestling kitsch? Specific provocative images promoted by bands can only be considered as countercultural in context: multiple scales must be taken into consideration, as everything depends on what one considers as the dominant culture targeted by a particular genre, band or song, and the criteria chosen to define its main signification. To insist on the multiplicity of signifying practices (De Certeau 1990, 239-242), on the spectator's activity, against the types of "distribution of the sensible" (Rancière 2000, 12) that the idea of passivity contains, is to accept the frailty and ideological and political relativity of any "counter"culture. Its identity or boundaries are then to be negotiated in a power struggle involving the agents of a cultural polemic (or "war"), the values chosen to judge these forms, the authority of the methods assessing their danger and the right to freedom of speech.

\section{KEY WORDS}

France - Hellfest - festival - local scene - metal - rock culture - popular music in France - youth - counter-culture - subculture - public sphere religion - Catholicism - politics - controversies - sign - signification government of senses - distribution of the sensible 


\section{BIBLIOGRAPHY}

Berger, Harris. 1999. Death Metal Tonality and the Act of Listening. In Popular Music 18/2: 161-178. Cambridge: Cambridge University Press.

Bobineau, Olivier (ed.). 2008. Le satanisme. Quel danger pour la société ? Paris: Flammarion-Pygmalion.

Chelley, Isabelle and Philippe Manœuvre. 2010. L'inconscience de la jeunesse. Interview de Ben Barbaud. Rock \& Folk 514: 16-19. Paris: Éditions Larivière.

Culat, Robert. 2007. L’Âge du metal. Rosières-en-Haye: Camion Blanc.

De Certeau, Michel. 1990. L'Invention du quotidien, t.1, Arts de faire. Paris: Gallimard.

Domergue, Benoît. 2000. Culture barock et Gothic flamboyant. La musique extrême : un écho surgi des abîmes. Paris: François Xavier de Guibert.

Foucault, Michel. 1976. Histoire de la Sexualité, t.1, La Volonté de savoir. Paris: Gallimard.

Foucault, Michel. 2004. Sécurité, Territoire, Population : Cours au Collège de France (1977-78). Paris: Seuil.

Fraser, Nancy. 1992. Rethinking the public sphere: a contribution to a critique of actually existing democracy. In Habermas and the Public Sphere ed. Craig Calhoun, 109-142. Cambridge: MIT Press.

Guibert, Gérôme and Fabien Hein (eds.). 2007. Les Scènes metal, in Copyright Volume! 5/2. Bordeaux: Mélanie Seteun.

Guibert, Gérôme. 2008. Les festivals musiques actuelles en Pays de la Loire. Entre logiques d'implantations locales et reconfigurations nationales. In $L e$ Pôle, Enquête Flash 1: 1-12.

Habermas, Jürgen. 1997. L'Espace public : archéologie de la publicité comme dimension constitutive de la société bourgeoise. Paris: Payot. 
Hein, Fabien. 2006. Rock \& Religion. Dieu(x) et la musique du diable. Boulogne Billancourt: Autour du Livre.

Kahn-Harris, Keith. 2002. I Hate this fucking country": Dealing with the Global and the Local in the Israeli Extreme Metal Scene. In Music, Popular Culture, Identities, ed. Richard Young: 119-136. Amsterdam: Rodopi.

Kahn-Harris, Keith. 2003. Death Metal and the Limits of Musical Expression. In Cloonan, Martin and Reebee Garofalo (eds.). Policing Pop: 81-99. Philadelphia: Temple University Press.

Miviludes. 2004. Report "Satanisme et dérive sectaire. Quels sont les risques, comment les prévenir ?’. Paris.

Miviludes. 2006. Le satanisme. Un risque de dérive sectaire. Paris: La Documentation française.

Rancière, Jacques. 2000. Le Partage du sensible. Esthétique et politique. Paris: La Fabrique.

Rancière, Jacques. 2008. Le Spectateur émancipé. Paris: La Fabrique.

Sklower, Jedediah. 2008. Rebel with the wrong cause. Albert Ayler et la signification du free jazz en France (1959-1971). In Copyright Volume! 61/2: 193-219. Bordeaux: Mélanie Seteun.

Schlegel, Jean-Louis. 2009. Benoît XVI et les intégristes : tempête sur l'Église, in Esprit 353: 7-16. Paris: Esprit.

Walser, Robert. 1993. Running with the Devil. Power, Gender, and Madness in Heavy Metal Music. Middletown: Wesleyan University Press.

Weinstein, Deena. 2000. Heavy Metal: The Music and its Culture. New York: Da Capo Press.

Weinstein, Deena. 2009. The Empowering Masculinity of British Heavy Metal in Gerd Bayer, Heavy Metal Music In Britain. London. Ashgate.

Wright, Robert. 2000. "I'd Sell You Suicide": Pop Music and Moral Panic in the Age of Marilyn Manson, in Popular Music 19/3: 365-385. Cambridge: 


\section{Cambridge University Press.}

i "You mustn't imagine The Good Lord's children just dropped out of trees"

ii Bill Hicks refers to the 1990 James Vance vs. Judas Priest trial.

iii As can be seen in accounts by the local press (Ouest France, Hebdo Sèvre et Maine...).

iv The album Christ Illusion 2006. American Recordings. B003CSCHUS.

Talking about Metal or techno music concerts, he says, elsewhere: "The human intelligence and will are not directly concerned by these stimuli, but a true "hypersaturation" of the senses and an exacerbated imagination are practically capable of isolating them. This conditioning and this oppression [...] are such, that cases of infestations or possessions can be imagined in such circumstances". See Le Subliminal. Interview $\mathrm{du}$ Père Domergue. http://www.lesubliminal.fr/interview_du_pere_domergue_193.htm.

vi The Miviludes' method and conclusions were severely criticized by one of the members of the commission working on Satanism, sociologist Olivier Bobineau (Bobineau 2008), who lead a collective counter-survey on the question, concluding there was barely any Satanist sectarian risk in France.

vii They are an emanation of Jean Ousset's "Cité catholique", a "nationalcatholic", former member of Charles Maurras' "Action Française" (the inglorious royalist and anti-Semitic league created at the end of the XIX ${ }^{\text {th }}$ century), and member of the "Jeune légion", an armed wing of the Vichy regime.

viii See Kaosguards. Ben Barbaud, Organisateur du Hellfest. http://www.kaosguards.com/content/view/699/35/.

For a synthesis of conservative catholic blogs and websites about the 2009 edition, see: Christ Roi blog. Synthèse des mobilisations contre le Hellfest et ses soutiens. http://christroi.over-blog.com/article-32838939.html

$x \quad$ Among the latter is the site e-deo.typepad.fr, which explicitly refers to the "real country" (pays réel), a concept that refers once again to the ideology of Charles Maurras, see supra, n. 4. The site's tone is constantly xenophobic and islamophobic.

xi Soutenons

http://www.facebook.com/group.php?gid=92490879863

Support group:

le

Hellfest !!!

http://www.facebook.com/group.php?gid=95531469014

"Je suis chrétien et j'écoute du metal. Et ce n'est pas contradictoire". http://frfr.facebook.com/group.php?gid=22098979270.

xii The petition can be accessed here: www.lepole.asso.fr/fichiers/file/petition\%20Hellfest(3).pdf

xiii Leader of very influential death metal band Death, who died in December 2001 of collateral damage from his cancer treatment (pneumonia). During the years 2000 and 2001, Metal bands gave charity concerts, fans sent money to pay for his first surgery.

xiv See Padre Bob blog. Qui sont les vrais satanistes? http://www.myspace.com/agedumetal/blog.

xv One can find on his myspace blog the copy of a post in favor of the Swiss "anti-minaret" November 2009 vote. See Ibid. Le Benditisme a encore frappé. 
xvi The letter can be here:

http://www.partichretiendemocrate.fr/images/stories/downloads/lettre\%20a\%20thoma s\%20amstutz-pdg\%20des\%20brasseries\%20kronenbourg.pdf

xvii The link to the video: http://videos.tf1.fr/sept-a-huit/la-guerre-des-mondes5898258.html.

xviii In his December $20^{\text {th }}, 2007$ speech at the Lateran, Mr. Sarkozy created quite a scandal back in France, for saying that "teachers will never be able to replace the priest or the pastor" in the moral education of our children. The speech can be accessed here: http://www.elysee.fr/president/les-actualites/discours/2007/allocutionde-m-le-president-de-la-republique.7012.html?search=Latran. 